\title{
Refutation by Elimination
}

\author{
Forthcoming in Analysis \\ John Turri \\ Huron University College \\ john.turri@gmail.com
}

This paper refutes two important and influential views in one fell stroke. The first is G.E. Moore's view that assertions of the form ' $\mathrm{Q}$ but I don't believe that Q' are inherently "absurd." The second is Gareth Evans's view that justification to assert Q entails justification to assert that you believe Q. Both views run aground the possibility of being justified in accepting eliminativism about belief. A corollary is that a principle recently defended by John Williams is also false, namely, that justification to believe $Q$ entails justification to believe that you believe $\mathrm{Q}$.

\section{Moore's Paradox}

You might be so absorbed in this paper that you don't notice that it's raining. It could be raining even though you don't believe that it's raining. If I notice this happening to you, I could felicitously report, "Funny thing - it's raining, but you don't believe it is." Or a 
third party might say of me, “It's raining, but John doesn't believe it's raining." You might even felicitously say of your past self, "It was raining, but I didn't believe that it was."

Despite all of that, as G.E. Moore famously pointed out, it is "absurd" to say, "It's raining, but I don't believe it is" (Moore 1942: 543, cited by Green and Williams 2007: 3). Any sincere utterance of the form 'Q but I don't believe that Q' sounds "absurd." Call these Moorean assertions. Virtually everyone agrees with Moore here. Or if they think 'absurd' is too strong, they'll at least agree that such assertions do sound exceedingly odd.

But why do they sound odd or absurd when they might possibly be true? That question gives rise to Moore's Paradox, a topic of considerable importance and intense debate, with numerous competing accounts on offer. My purpose here is not to survey or evaluate proposals. I disagree with the consensus evaluation of such assertions as inherently absurd. They're not always absurd, and one principal lesson of my discussion is that the correct response to Moore's Paradox must allow for this, and preferably help us understand why such exceptions exist.

We ignore contrived examples of the following sort, involving the eternal present tense. I'm deceived into thinking that it isn't raining when it in fact is. This is all video-recorded. Later my tormenters inform me of these developments and show me the recording. Upon viewing it, I say, "Oh, look. It's raining, but I don't believe it is." This doesn't sound absurd, but it's not the sort of case Moore and others have in mind. 


\section{Evans's Principle}

Reflecting on some "gnomic" remarks from Wittgenstein led Gareth Evans (1982: 225 - 6) to what he thought was an important insight, which has since been influential.

In making a self-ascription of belief, one's eyes are, so to speak, or occasionally literally, directed outward-upon the world. If someone asks me 'Do you think there is going to be a third world war?', I must attend, in answering him, to precisely the same outward phenomena as I would attend to if I were answering the question 'Will there be a third world war?'[.] I get myself in a position to answer the question whether I believe that $p$ by putting into operation whatever procedure I have for answering the question whether $p . .$. If a judging subject applies this procedure, then necessarily he will gain knowledge of one of his own mental states: even the most determined skeptic cannot find here a gap in which to insert a knife.

We can encapsulate this procedure for answering questions about what one believes in the following simple rule: whenever you are in a position to assert that $p$, you are ipso facto in a position to assert 'I believe that $p$ '.

Call the view stated here Evans's Principle: whatever makes it 
reasonable for you to assert $\mathrm{Q}$ likewise makes it reasonable for you to assert that you believe Q. I think the 'ipso facto' supports this stronger reading. But a weaker reading will suffice for my purposes: if it's reasonable for you to assert $Q$, then it's reasonable for you to assert that you believe Q.

Inspired by Evans, John Williams (2004: 349 - 50) has recently defended a related principle. Williams claims, "Whatever justifies me in believing that $p$ also justifies me in believing that I believe that $p$. " Call this Williams's Principle. ${ }^{2}$

\section{Elimination}

Ellie is an eliminativist about propositional attitudes. She has read cutting edge work in philosophy and cognitive science that makes a very persuasive case that propositional attitudes are not real. (Imagine that she has read, among other things, work similar to, but even more compelling than, the work contained in the "Eliminativism about Propositional Attitudes" section of the "Mind Papers" database: <http://consc.net/mindpapers/2.1c >.) Ellie is not a professional philosopher or cognitive scientist. But she is very intelligent and well educated. She understands the arguments. And she knows enough history of science to know that it's not unprecedented for science to discredit erstwhile articles of commonsense. The sun doesn't revolve around the earth, the earth isn't flat, and hu-

2 I disagree with Williams's interpretation of the Evans passage quoted above, but those details needn't detain us here. 
mans evolved from primitive life forms. "Now we can add to that list that there are no propositional attitudes," she concludes.

Ellie's total body of evidence strongly supports the view that there are no propositional attitudes, and consequently that there are no beliefs, and consequently that she does not believe anything. We know that Ellie is wrong-eliminativism is false-but it's possible to be justified in accepting false things. ${ }^{3}$ And Ellie is justified in believing that there are no beliefs.

Now Ellie is having lunch with her friends, who are just as intelligent and well educated as her. She explains the case for eliminativism to them. They're impressed, and rightly so. But old habits die hard. One of her friends asks, "Eliminativism certainly seems true, Ellie. Is this your considered view? Do you really believe it?” Ellie responds, "Eliminativism is true, but of course I don't believe it's true. There are no beliefs!" Ellie might go on to make many other similar assertions, such as, "The waiter brought me the wrong dish, but I don't believe he did," "This tablecloth is dirty, but I don't believe it is," "It's raining, but I don't believe it is," etc.

Ellie's sincere, unambiguous, forthright assertions are not only felicitous, but perfectly reasonable. No one is befuddled. No one thinks them absurd, because they aren't absurd. And yet they fit the standard Moorean mold. Moorean assertion is not inherently absurd.

The same example shows that Williams's Principle is false. Wil-

${ }^{3}$ Sutton 2007 dissents, but not persuasively enough. 
liams said that if something justifies you in believing Q, it justifies you in believing that you believe Q. The two beliefs that Ellie expresses by making that assertion are themselves fully reasonable. She is justified in believing that eliminativism is true, but she is not justified in believing that she believes that eliminativism is true. Indeed, she's justified in believing that she does not believe that eliminativism is true. She's justified in believing that the waiter brought the wrong dish, but not justified in believing that she believes this. Etc.

The same example shows that Evans's Principle is false. Evans said that if it is reasonable for you to assert Q, then it's reasonable for you to assert that you believe Q. But the evidence that makes it reasonable for Ellie to assert that eliminativism is true certainly does not make it reasonable for her to assert that she believes that eliminativism is true. Indeed, it would have sounded absurd had she said, "Eliminativism is true, and I believe it is." 


\section{References}

Evans, Gareth. 1982. The Varieties of Reference. Ed. John McDowell. New York: Oxford University Press.

Green, Mitchell S. and John N. Williams. 2007. Moore's Paradox: New Essays on Belief, Rationality and the First-Person. New York: Oxford University Press.

Moore, G.E. 1942. "A Reply to My Critics." In The Philosophy of G.E. Moore (La Salle, Ill.: Open Court), ed. P. Schilpp.

Sutton, John. 2007. Without Justification. Cambridge, MA: MIT Press.

Williams, John N. 2004. "Moore's Paradoxes, Evans's Principle, and Self-knowledge." Analysis 64:4 (Oct. 2004), 348 - 53. 